\title{
Met-Enkephalin Involvement in Morphine-Modulated Peritonitis in Swiss Mice
}

\author{
Magdalena Chadzinska, ${ }^{1}$ Anna Scislowska-Czarnecka, ${ }^{1}$ Krystyna Pierzchala-Koziec, ${ }^{2}$ and Barbara Plytycz ${ }^{1}$ \\ ${ }^{1}$ Department of Evolutionary Immunobiology, The Institute of Zoology, \\ Jagiellonian University, Ingardena 6, 30-060 Kraków, Poland \\ ${ }^{2}$ Department of Animal Physiology, Academy of Agriculture, Mickiewicza 24/28, 31-059 Kraków, Poland
}

Received 9 November 2004; accepted 20 December 2004

\begin{abstract}
Morphine coinjection with zymosan inhibits pain and leukocyte accumulation during peritonitis in several strains of mice, and affects systems of endogenous opioids. Present investigations focus on Met-enkephalin (Met-ENK) in the inflamed peritoneal cavity and brain centers of Swiss mice. Males of Swiss mice were IP injected with zymosan or zymosan supplemented with morphine. At the selected time points the peritoneal leukocytes were counted and the Met-ENK level was measured in exudatory fluid and leukocytes, striatum, hypothalamus, and pituitary gland. The Met-ENK content in peritoneal fluid rised sharply after zymosan injection, which corresponded with its decline in exudatory leukocytes, hypothalamus, and striatum. Morphine coinjection enhanced intraperitoneal accumulation of Met-ENK and its release from exudatory leukocytes, but inhibited its early fluctuations in hypothalamus and striatum. Effects of morphine-modulated inflammation on the Met-ENK system lasted longer than 7 days.
\end{abstract}

\section{INTRODUCTION}

The immune system plays an important role in the pain control, especially under inflammatory conditions. As evidenced in series of experiments on adjuvantinduced paw inflammation in the rat, opioid receptors on peripheral sensory nerve terminals in the inflamed tissue are upregulated and activated by opioid peptides derived from immunocytes accumulated in the focus of inflammation resulting in potent analgesia $[1,2]$.

We wish to draw attention to another model for investigations of the opioid system participation in the inflammatory processes, namely to experimental peritonitis induced by intraperitoneal (IP) injection of a sterile stimulant, for example, zymosan. The convenience of this model consists in the possibility of a precise quantification of inflammation-related cells and soluble factors in samples of exudatory fluid quantitatively retrieved from the control or inflamed peritoneal cavity $[3,4,5]$. We have shown that the supplementation of a stimulant with exogenous opioid, morphine, affects inflammation in a naltrexone-reversed manner, that is, through the binding of opioid receptors. Morphine co-administration significantly reduces the levels of chemotactic factors and the number of inflammatory leukocytes in several (but

Correspondence and reprint requests to Magdalena Chadzinska, Department of Evolutionary Immunobiology, The Institute of Zoology, Jagiellonian University, Ingardena 6, 30-060 Kraków, Poland; chadz@zuk.iz.uj.edu.pl not all) strains of mice $[3,5,6,7]$, in the two investigated fish species, goldfish and Atlantic salmon $[3,8,9]$, but in none of the three investigated species of anuran amphibians $[9,10]$ with experimental peritonitis. The morphine-induced inhibition of early stages of peritonitis corresponds with an inhibited in vitro migration of mice and fish (but not frogs) morphine-treated leukocytes to zymosan-activated serum [11].

In mice, early stages of zymosan-induced peritonitis are accompanied by characteristic body writhes considered to be visceral pain symptoms [12]. Morphine supplementation of the irritant completely eliminates body writhes even at the low doses ( 5 or $10 \mathrm{mg} / \mathrm{kg} \mathrm{BW}$ ) while, at the high dose $(20 \mathrm{mg} / \mathrm{kg} \mathrm{BW})$, additionally inhibits influx of leukocytes in four out of the five investigated strains of mice, including the Swiss $[5,6,7]$. Therefore, local morphine administration might offer double profits during planned surgeries, being both antinociceptive and antiinflammatory [5]. Such a morphine-dependent modification of the inflammatory process would seem to be advantageous for the host, since some inflammation-related cells and molecules at the high concentration and/or during prolonged action might be detrimental [5].

We may speculate that morphine added to an inflammatory stimulant can interplay with endogenous opioids so as to support their antinociceptive function in the focus of inflammation and, as a consequence, lead to the inhibition of influx and accumulation of new leukocytes. In a series of the ongoing experiments we investigate the effects of exogenous morphine on systems of endogenous 
opioids during experimental peritonitis in Swiss mice. It turned out that morphine coinjection affects the proopiomelanocortin (POMC) and prodynorphin (PDYN) systems on the levels of mRNAs for respective peptides and their receptors on inflammatory leukocytes as well as the accumulation of peptides in the focus of inflammation [13]. In the case of the proenkephalin (PENK) system we detected the upregulated level of PENK mRNA in exudatory leukocytes [14], but despite the strong efforts we were unable to detect mRNA for delta opioid receptors on Swiss mice peritoneal leukocytes (PTLs) [13]. We have also shown a local increase in the Met-enkephalin (MetENK) level in the focus of inflammation with its parallel decrease in the lymph nodes and distant neurohormonal centers 4 hours after zymosan-induced peritonitis in Swiss mice. This implies the dual origin of this peptide from both locally accumulated leukocytes and distal neurohormonal centers [15]. The goal of the present study was to extend those preliminary observations by recording the time course of Met-ENK changes in the focus of inflammation and some brain areas. The second goal was to check if the coinjection of the anti-inflammatory dose of morphine would affect zymosan-induced fluctuations in the local and distant Met-ENK levels.

\section{MATERIALS AND METHODS}

\section{Animals}

Adult male Swiss mice, purchased from the commercial supplier (Breeding of Laboratory Animals, Collegium Medicum, Krakow, Poland), were kept in $20 \times 13 \times 18 \mathrm{~cm}^{3}$ cages (four mice per cage) in a room with controlled temperature $\left(22^{\circ} \mathrm{C}\right)$ and lighting (lights on 8:00-20:00). Food (standard mouse laboratory chow) and water were available ad libitum. Animals were 6-8 weeks of age (25$30 \mathrm{~g}$ body weight) at the beginning of the investigations. The experiments were conducted according to License no. 16/OP/2001 from the Local Ethical Committee.

\section{Schedule of drug administration and experimental protocol}

Animals were either left untreated (0 time) or injected IP with freshly prepared zymosan ( $\mathrm{Z}$ groups) ( $2 \mathrm{mg} / \mathrm{mL}, 0.5 \mathrm{~mL} / 25 \mathrm{~g}$ BW) (zymosan A, Sigma, St Louis, Mo) in sterile PBS, or with zymosan supplemented with morphine hydrochloride (ZM groups) $(20 \mathrm{mg} / \mathrm{kg}$ BW; Polfa, Kutno, Poland). Animals were killed at selected time points and their peritoneal cavities were lavaged with $1 \mathrm{~mL}$ of PBS. Peritoneal cells were Turk-stained and counted with a hemocytometer. Peritoneal fluid (PF) and peripheral blood were centrifuged (15 minutes, $1500 \mathrm{rpm})$, then supernatants and blood plasma were stored at $-20^{\circ} \mathrm{C}$ for future analysis. Selected brain areas (hypothalamus, pituitary gland, striatum) were dissected and kept frozen $\left(-70^{\circ} \mathrm{C}\right)$ until used. All experiments were repeated at least twice with at least 3 animals per group.

\section{Nociceptive activity}

Nociceptive activity was tested using the writhing model [12]. Characteristic body writhes (consisting of a contraction of the abdominal muscles together with a stretching of hind limbs) were counted during fiveminute intervals for each mouse.

\section{Met-ENK detection}

Met-ENK levels were measured in homogenates of the brain structures (striatum, hypothalamus, pituitary glands), pellets of peritoneal cells, and PF. Brain structures were quickly removed and frozen on dry ice. Weighed tissues were homogenized in chilled phosphate buffer $(\mathrm{pH}$ $=6.5,1: 10 \mathrm{w} / \mathrm{v}$ ) using Ultra-Turrax $\mathrm{T} 8$, then centrifuged for 30 minutes, $4000 \mathrm{rpm}$, at $4{ }^{\circ} \mathrm{C}$, samples were stored at $-70{ }^{\circ} \mathrm{C}$ until performing the assay.

Native enkephalin was purified on Porapak columns comprised of Porapak Q 100-120 mesh (Waters, Milford, Mass) in $3 \mathrm{~mL}$ of absolute ethanol. Porapak slurry was prepared by degassing overnight $25 \mathrm{~g}$ of the material in $350 \mathrm{~mL}$ of absolute ethanol. Shortly before applying the samples, columns were washed with $6 \mathrm{~mL}$ of absolute ethanol and equilibrated with $9 \mathrm{~mL}$ of doubly distilled water. Columns loaded with the samples were washed with $6 \mathrm{~mL}$ of doubly distilled water and native enkephalin was eluted with $3 \mathrm{~mL}$ of absolute ethanol, then lyophilized and held at $4{ }^{\circ} \mathrm{C}$ until assay within 2 days.

Met-ENK immunoreactivity was quantitated using commercial antiserum developed in rabbit (Bachem, Baden-Wuerttemberg, Germany), ${ }^{125}$ I-Met-enkephalin (New England Nuclear, Boston, Mass) and Met-ENK standard (Peninsula, San Carlos, Calif). The antiserum was used in a final dilution of 1:12000; it showed cross-reactivity of $100 \%$ with Met-enkephalin sulfoxide, $2 \%$ with Leu-enkephalin and less than $1 \%$ with Metenkephalin-Arg-Phe, Met-enkephalin-Arg-Gly-Leu, or $\beta$ endorphin. Intra-assay and interassay coefficients of variation for the assay are 7 and 11 percent, respectively. Recovery of standard Met-ENK added to the samples and carried through the entire extraction and radioimmunoassay procedures was $79 \%$ [16].

\section{Statistical analysis}

The results were statistically analyzed by 2-way ANOVA (to check if the time course of ZM groups differs significantly from that of $\mathrm{Z}$ groups) with post hoc Tukey's test (indicating the time points with means significantly different). The differences were considered statistically significant at $P<.05$.

\section{RESULTS}

\section{Time course of peritonitis induced by injection with Z or ZM in Swiss mice}

Values at particular time points were compared with the level at time 0 as well as between the $\mathrm{Z}$ and $\mathrm{ZM}$ groups of animals. See Figure 1. 


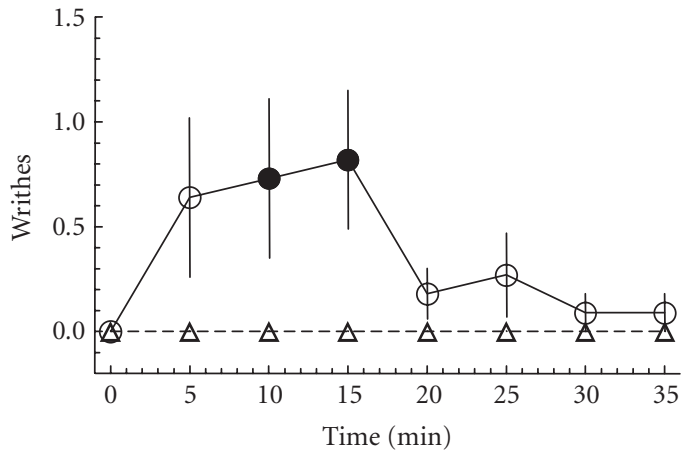

$\ominus \mathrm{z}$

$-A-Z M$

(a)

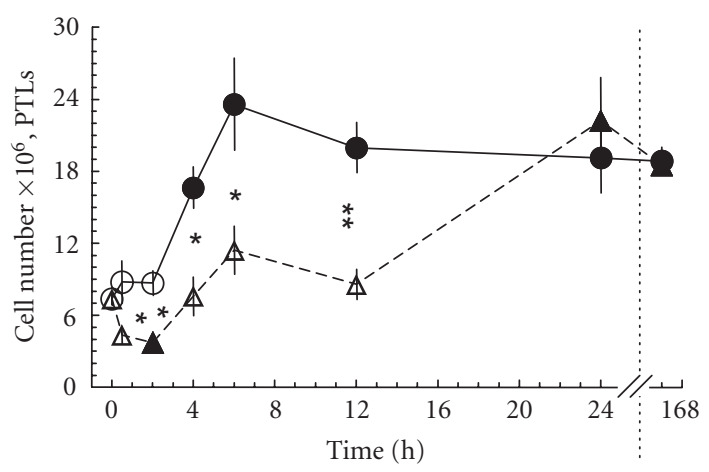

$\bigcirc \mathrm{Z}$

$-\Delta-\mathrm{ZM}$

(b)

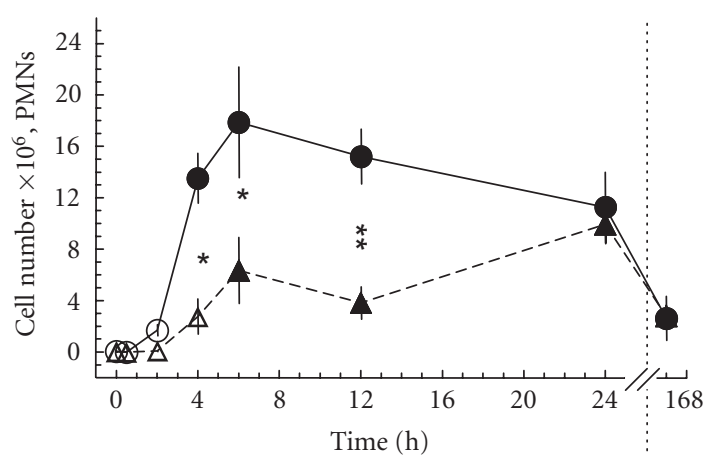

$\ominus \mathrm{Z}$

$-A-Z M$

(c)

Figure 1. Time course of inflammation-related parameters in males of Swiss mice either intact (time 0) or IP injected with zymosan (Z, solid lines and circles) or zymosan with morphine (ZM, broken lines and triangles). (a) Number of body writhes; peritoneal cell numbers; (b) total peritoneal leukocytes (PTLs); (c) polimorphonuclear leukocytes (PMNs). The results are expressed as $\mathrm{X}+\mathrm{SE}, n=4-8$. Solid symbols indicate means significantly different from time 0 according to ANOVA at $P<.05$; asterisks between significantly different means of $\mathrm{Z}$ and $\mathrm{ZM}$ groups at the given time point according to post hoc Tukey's test denote that $P<.05(*), P<.01(* *)$.

\section{Nociceptive activity}

Body writhes (pain symptoms) were compared between the animals from $\mathrm{ZM}$ and $\mathrm{Z}$ groups. The number of body writhes in the $\mathrm{Z}$ groups was high during the first 30 minutes after zymosan injection, while thereafter these symptoms were sporadic only. Body writhes were absent in the ZM groups of Swiss mice (Figure 1a).

\section{Time course of leukocyte accumulation}

The number of resident PTLs was low in the intact animals (time 0 ) while the total number of PTLs increased sharply between 2 and 6 hours after the zymosan injection and remained at a similarly high level for at least 7 days after injection (Figure 1b). Among them, PMNs dominated during the first 24 hours while on the 7th day intraperitoneal exudate consisted of mainly the mononuclear cells (Figure 1c).

The PTLs influx was significantly delayed in animals injected with zymosan supplemented with morphine (Figure 1b). Such a delay in PTLs accumulation in the focus of inflammation concerned mainly PMNs, which, nevertheless, eventually reached the level characteristic for the $\mathrm{Z}$ group 24 hours after injection (Figure 1c). The effects of morphine supplementation on the accumulation of mononuclear leukocytes were less drastic (not shown).

\section{Met-ENK fluctuations in the focus of inflammation}

After the irritant injection, the Met-ENK content was significantly increased in PF, significantly more in the ZM than in the $\mathrm{Z}$ groups of animals (Figure 2a). The content of Met-ENK in the total pellet of exudatory cells in the $\mathrm{Z}$ group was relatively stable with a peak only at the 4 th hour after the $\mathrm{Z}$ injection. This was apparently due to a sustained IP influx of new leukocytes that balanced the peptide release into PF. In contrast, the Met-ENK level was significantly decreased in PTLs of ZM animals that corresponded with the delayed influx of cells. Despite the similar PTLs numbers in the $\mathrm{Z}$ and ZM groups of animals on the 7th day of peritonitis, the Met-ENK content of PTLs was higher in the $\mathrm{Z}$ than $\mathrm{ZM}$ groups, which suggests its enhanced release to PF of ZM mice (Figure 2b). The MetENK levels in the same numbers $\left(10^{6}\right)$ of PTLs decreased significantly, more in the $\mathrm{ZM}$ than $\mathrm{Z}$ groups of animals (Figure 2c).

\section{Met-ENK fluctuations in brain centers}

A sudden drop of Met-ENK in the brain centers (striatum and hypothalamus) of zymosan-injected animals was reversed by the morphine coinjection (Figures $2 \mathrm{~d}$ and $2 \mathrm{e})$. On the 7th day after injection, the level of Met-ENK was still different from that in the control in the striatum (lower in the $\mathrm{Z}$ and higher in $\mathrm{ZM}$ groups) and in hypothalamus (decreased in both Z and ZM animals) (Figures $2 \mathrm{~d}$ and 2e). Drastic fluctuations of Met-ENK in the pituitary gland of the Z group of animals were smoothed in the ZM groups of mice (Figure 2f). Met-ENK was at the control level on the 7th day in the pituitary gland (Figure 2f). 


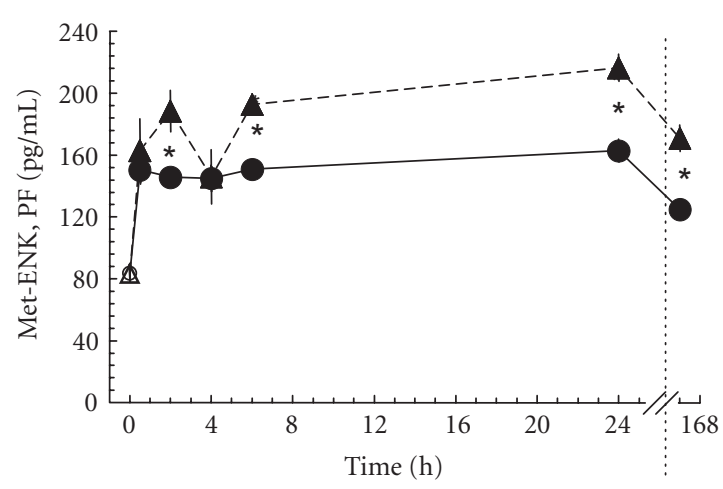

$\ominus \mathrm{Z}$

$-A-Z M$

(a)

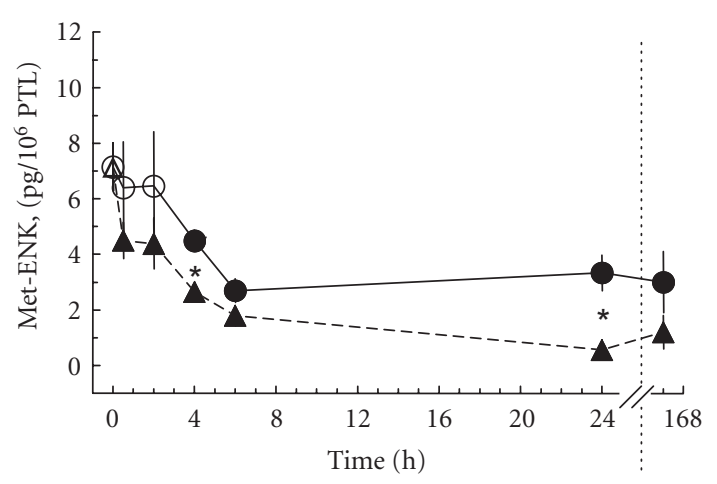

$\bigcirc \mathrm{z}$

$-\Delta-\mathrm{ZM}$

(c)

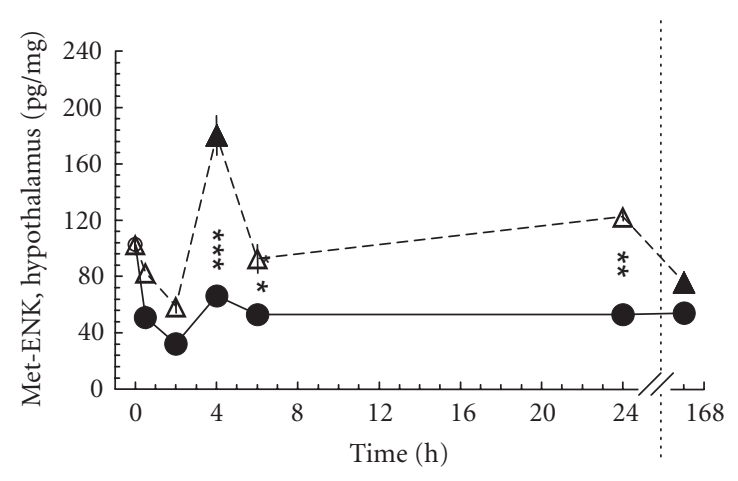

$\ominus z$

$-\Delta-Z M$

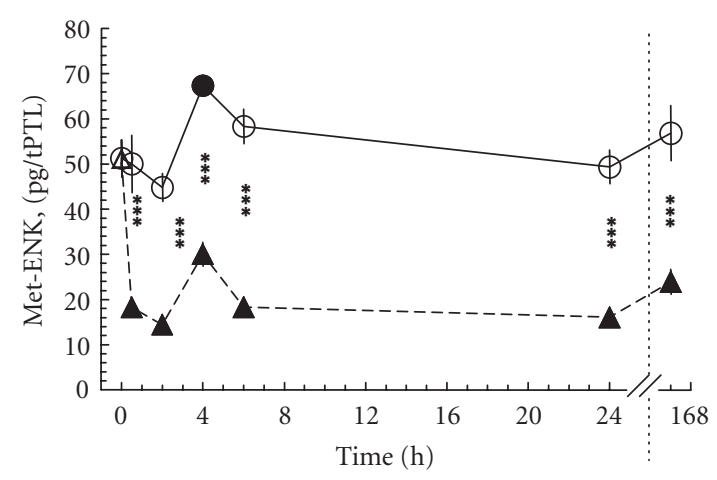

$\ominus \mathrm{Z}$

$-A-Z M$

(b)

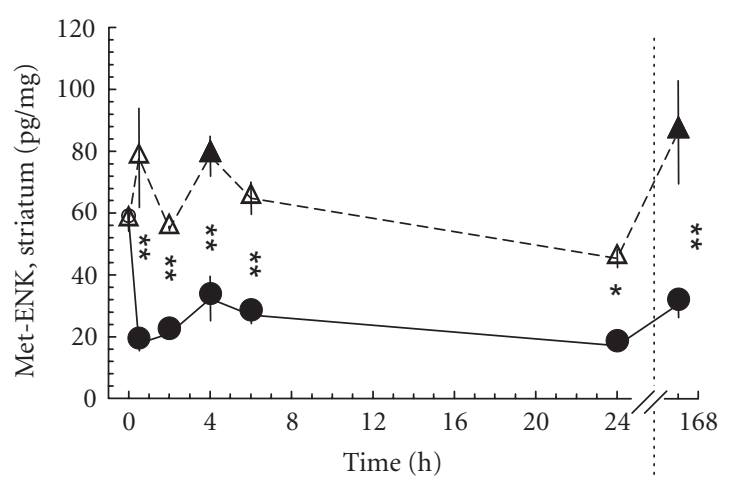

$\bigcirc \mathrm{z}$

$-\Delta-\mathrm{ZM}$

(d)

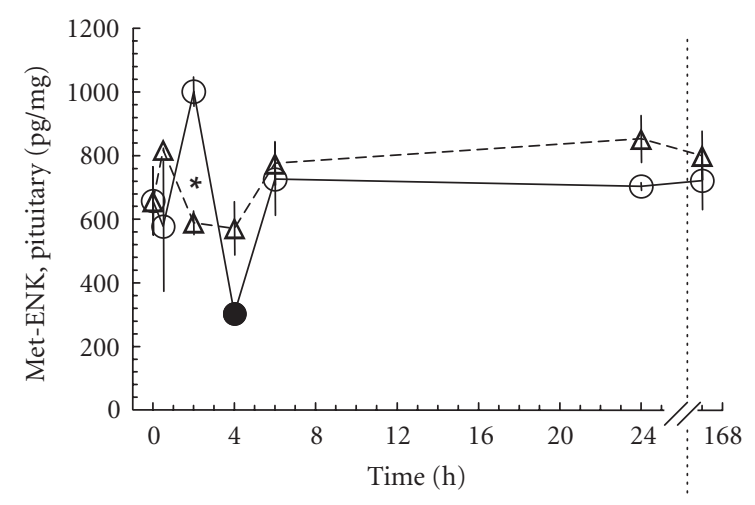

$\bigcirc \mathrm{Z}$

$-\Delta-Z M$

(e)

(f)

Figure 2. Time course of Met-enkephalin levels in males of Swiss mice either intact (time 0) or IP injected with zymosan (Z, solid lines and circles) or zymosan with morphine (ZM, broken lines and triangles) in (a) peritoneal fluid (PF); (b) total pool of PTLs; (c) $10^{6}$ PTLs; (d) striatum; (e) hypothalamus; (f) pituitary gland. The results are expressed as X+ SE, $n=4-8$. Solid symbols indicate means significantly different from time 0 according to ANOVA at $P<.05$; asterisks between significantly different means of $\mathrm{Z}$ and $\mathrm{ZM}$ groups at the given time point according to post hoc Tukey's test denote that $P<.05(*) ; P<.01(* *) ; P<.001(* * *)$. 


\section{DISCUSSION}

The zymosan-induced peritonitis described here follows a typical pattern of inflammatory reaction with a rapid accumulation of PMNs during the initial 24 hours followed by mononuclear leukocytes dominating in peritoneal cavity on the 7th day (Figure 1). The early influx of leukocytes is accompanied with a pronounced IP accumulation of cytokines, both classical proinflammatory factors such as IL-1 $\beta$, TNF, IL-6, KC, MCP-1 [17], and also endogenous opioids, namely, $\beta$-endorphin, dynorphin [13], and Met-ENK $[14,15]$, which make up the best characterized endogenous analgesic system [18]. Therefore it is not surprising that behavioral episodes reflecting visceral pain, namely, the characteristic body writhes of mice with peritonitis, are relatively short lasting, as they are frequent mostly during the first 30 minutes after zymosan injection (Figure 1a, [7, 12]). The endogenous peptides can act antinociceptively on the opioid receptors on the local nerve endings, as evidenced in a case of adjuvant-induced paw inflammation in rats [18]. The opioid receptors on the nerve endings are gradually upregulated in a focus of inflammation. The initial low availability of opioid receptors may be partly responsible for the delay in the analgesic effects of rapidly accumulating opioid peptides (cf Figures $1 \mathrm{a}$ and $2 \mathrm{a}$ ), in addition to the early abundance of a variety of proanalgesic factors at the initiation of inflammation [1].

The results of the present and previous studies of experimental peritonitis indicate that opioids that accumulate in the inflamed peritoneal cavity may have dual origin, being released from both exudatory leukocytes and distant neurohormonal centers (Figure 2). Figure 2 illustrates that an IP zymosan injection triggers a rapid opioid release from the PTLs, striatum, hypothalamus, and pituitary gland. Apart from the opioids from the neurohormonal centers it seems that the wave of neutrophilderived peptides (dominating during the first 24 hours of peritonitis, Figure 1c) is followed by the peptides derived from the mononuclear leukocytes (dominating on the 7th day), similar to the sequence detected by immunohistochemistry during the rat paw inflammation [2].

Exogenous morphine shares receptors with opioid peptides [18] thus it is not surprising that the coinjection of morphine with zymosan affects the system of endogenous opioids in a different way than that induced by the injection of zymosan only (Figure 2, [13]). In general, an IP coinjection of a high dose of morphine inhibits the Met-ENK release from the brain centers or even induces their temporal accumulation. On the other hand, the morphine coinjection enhances the zymosan-induced accumulation of Met-ENK in PF on both the 1st and 7th days of peritonitis (Figure 2), which implies the leukocyte origin of the IP Met-ENK. The latter phenomenon is surprising as the IP influx of leukocytes is delayed in the ZM versus $Z$ groups of animals, while on the 7 th day the numbers of PTLs (both PMNs and mononuclear cells) are similar in the Z and ZM groups of mice (Figure 1). The accu- mulation of free Met-ENK in exudatory fluid may be connected with the occupation of opioid receptors by exogenous morphine. This phenomenon may explain the enhanced accumulation of free endogenous opioids soon after the morphine injection but not 7 days later. Therefore at present we may only conclude that morphine interplay with endogenous opioids during inflammation has longlasting effects.

\section{ACKNOWLEDGMENT}

This study was supported by Grant 6P04C 047 21 from the State Committee for Scientific Research, Warszawa, Poland.

\section{REFERENCES}

[1] Brack A, Labuz D, Schiltz A, et al. Tissue monocytes/macrophages in inflammation: hyperalgesia versus opioid-mediated peripheral antinociception. Anesthesiology. 2004;101(1):204-211.

[2] Machelska H, Schopohl JK, Mousa SA, Labuz D, Schafer M, Stein C. Different mechanisms of intrinsic pain inhibition in early and late inflammation. $J$ Neuroimmunol. 2003;141(1-2):30-39.

[3] Chadzinska M, Kolaczkowska E, Seljelid R, Plytycz B. Morphine modulation of peritoneal inflammation in Atlantic salmon and CB6 mice. J Leukoc Biol. 1999;65(5):590-596.

[4] Kolaczkowska E, Seljelid R, Plytycz B. Role of mast cells in zymosan-induced peritoneal inflammation in Balb/c and mast cell-deficient WBB6F1 mice. $J$ Leukoc Biol. 2001;69(1):33-42.

[5] Plytycz B, Natorska J. Morphine attenuates pain and prevents inflammation in experimental peritonitis. Trends Immunol. 2002;23(7):345-346.

[6] Stankiewicz E, Wypasek E, Plytycz B. Mast cells are responsible for the lack of anti-inflammatory effects of morphine in CBA mice. Mediators Inflamm. 2004;13(5-6):365-368.

[7] Natorska J, Plytycz B. Strain specific dissociation in the modulatory effects of morphine on zymosaninduced peritoneal inflammation in mice. NeuroImmunoModulation. In press.

[8] Chadzinska M, Scislowska-Czarnecka A, Plytycz B. Inhibitory effects of morphine on some inflammation-related parameters in the goldfish Carassius auratus L. Fish Shellfish Immunol. 2000;10(6):531-542.

[9] Chadzinska M, Kolaczkowska E, ScislowskaCzarnecka A, Van Rooijen N, Plytycz B. Effects of macrophage depletion on peritoneal inflammation in Swiss mice, edible frogs and goldfish. Folia Biologica (Krakow). 2004;52:225-231.

[10] Kolaczkowska E, Menaszek E, Seljelid R, Plytycz B. Experimental peritonitis in anuran amphibians is not suppressed by morphine treatment. Pol J Pharmacol. 2000;52(4):323-326. 
[11] Chadzinska M, Plytycz B. Differential migratory properties of mouse, fish, and frog leukocytes treated with agonists of opioid receptors. Dev Comp Immunol. 2004;28(9):949-958.

[12] Scislowska-Czarnecka A, Chadzinska M, PierzchalaKoziec K, Plytycz B. Long-lasting effects of social stress on peritoneal inflammation in some strains of mice. Folia Biol (Praha). 2004;52(1-2):97-104.

[13] Chadzinska M, Starowicz K, Scislowska-Czarnecka A, et al. Morphine-induced changes in the activity of proopiomelanocortin and prodynorphin systems in zymosan-induced peritonitis in mice. Int Immunopharmacol. In press.

[14] Chadzinska M, Maj M, Scislowska-Czarnecka A, Przewlocka B, Plytycz B. Expression of proenkephalin (PENK) mRNA in inflammatory leukocytes during experimental peritonitis in Swiss mice. Pol J Pharmacol. 2001;53(6):715-718.

[15] Chadzinska M, Scislowska-Czarnecka A, PierzchalaKoziec K, Plytycz B. Inflammation-induced alternations in local and central Met-enkephalin in mice. Pol J Pharmacol. 2003;55(3):467-470.

[16] Pierzchala K, Van Loon GR. Plasma native and peptidase-derivable Met-enkephalin responses to restraint stress in rats. Adaptation to repeated restraint. J Clin Invest. 1990;85(3):861-873.

[17] Chadzinska M, Scislowska-Czarnecka A, Plytycz B. Dissociated effects of morphine on mediators of zymosan-induced peritonitis in Swiss mice. In: Niemial Towski M, ed, Molecular Biology in Diagnostics of Infectious Diseases and Biotechnology. Warsaw, Poland: SGGW Press; 2004:36-39.

[18] Stein C, Schafer M, Machelska H. Attacking pain at its source: new perspectives on opioids. Nat Med. 2003;9(8):1003-1008. 


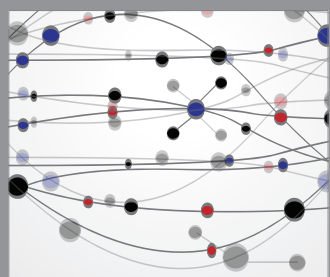

The Scientific World Journal
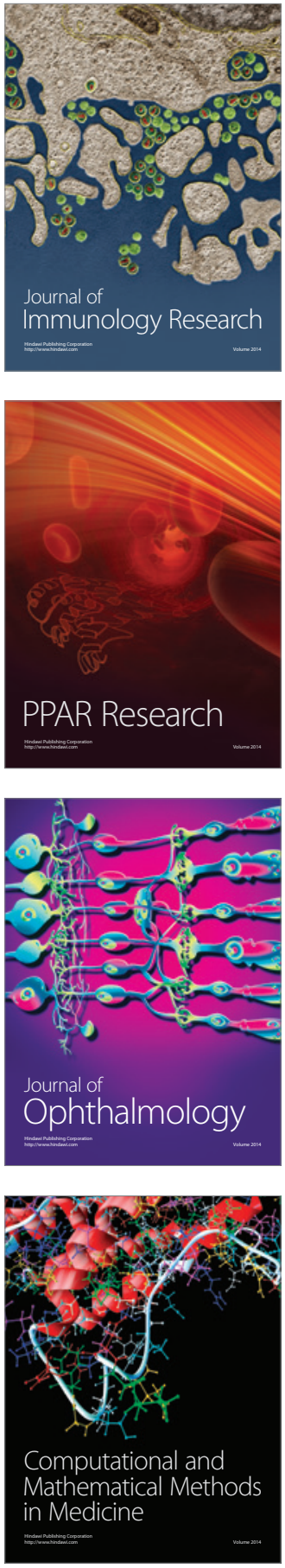

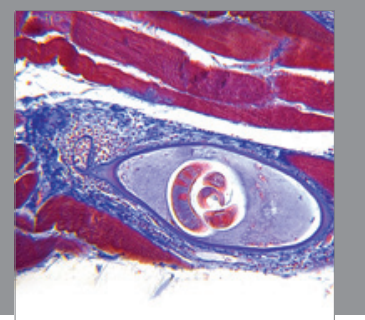

Gastroenterology

Research and Practice
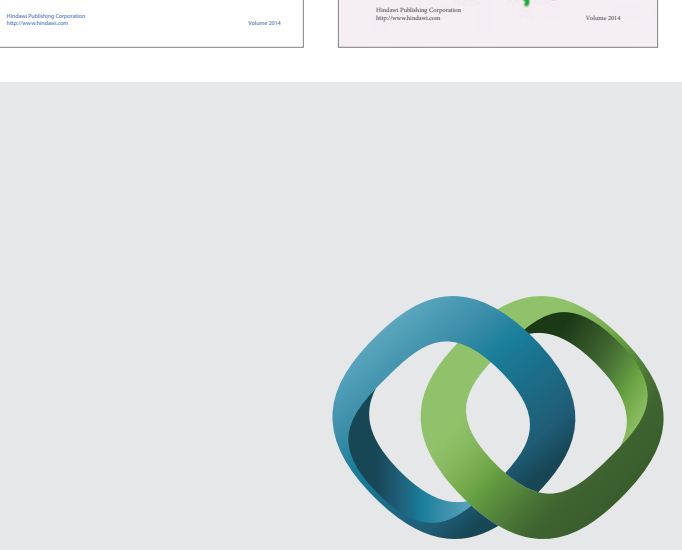

\section{Hindawi}

Submit your manuscripts at

http://www.hindawi.com
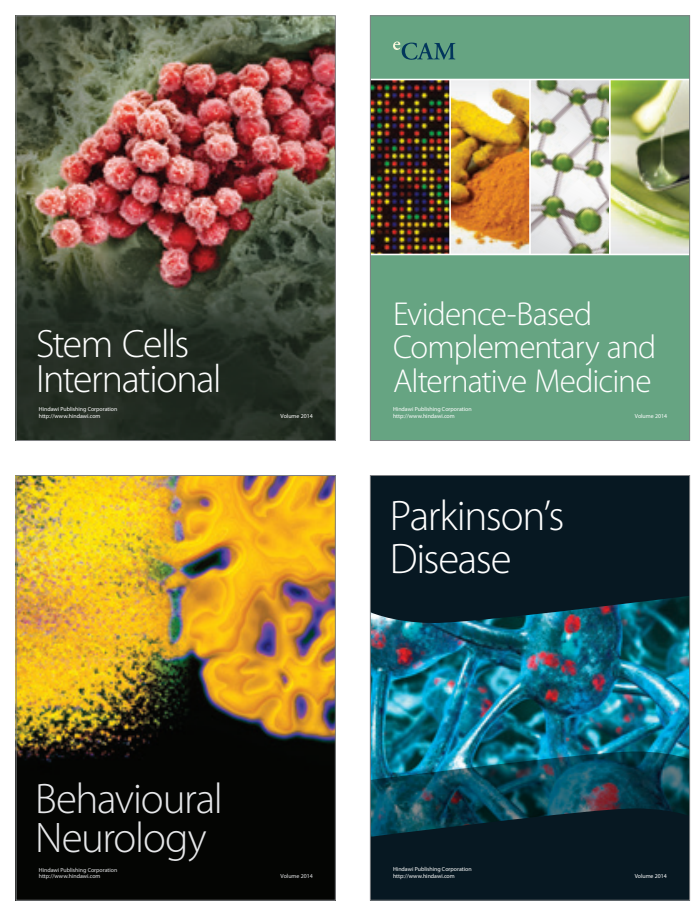

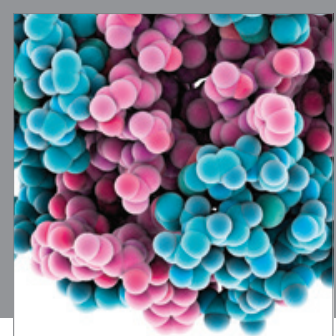

Journal of
Diabetes Research

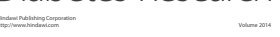

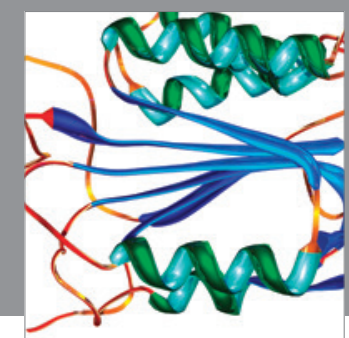

Disease Markers
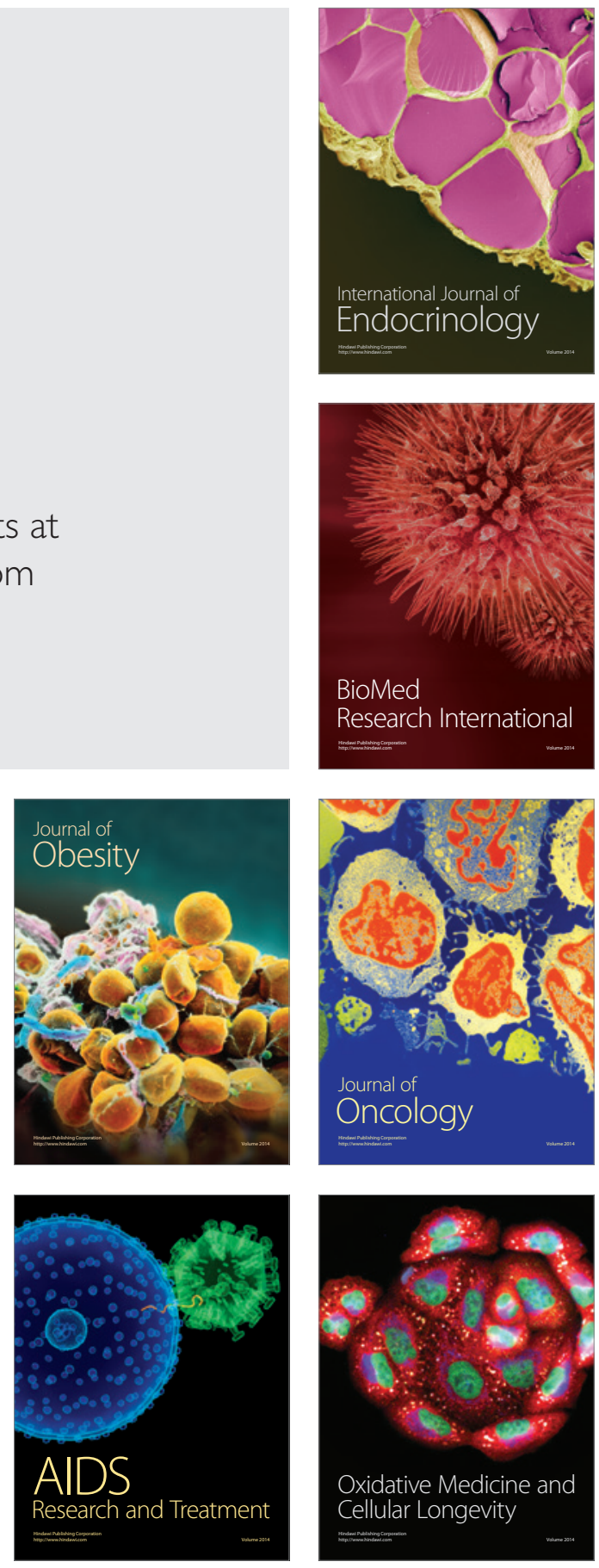